\title{
Use of MRI to detect duodenal lesion caused by eosinophilic duodenitis
}

\author{
Kartika Selvam, ${ }^{1}$ Ali Hassan, ${ }^{2}$ Farid Hossain ${ }^{3}$
}

${ }^{1}$ Accident and Emergency Department, Wexham Park Hospital, Berkshire, UK 2Department of Radiology, Wexham Park Hospital, Berkshire, UK

${ }^{3}$ Department of

Gastroenterology, Wexham

Park Hospital, Berkshire, UK

Correspondence to

Dr Kartika Selvam,

kartika.selvam@gmail.com

\section{DESCRIPTION}

A man in his mid-20s was admitted to the A\&E department with melaena and lower abdominal pain. He had been diagnosed with dyspepsia and duodenitis 4 years back.
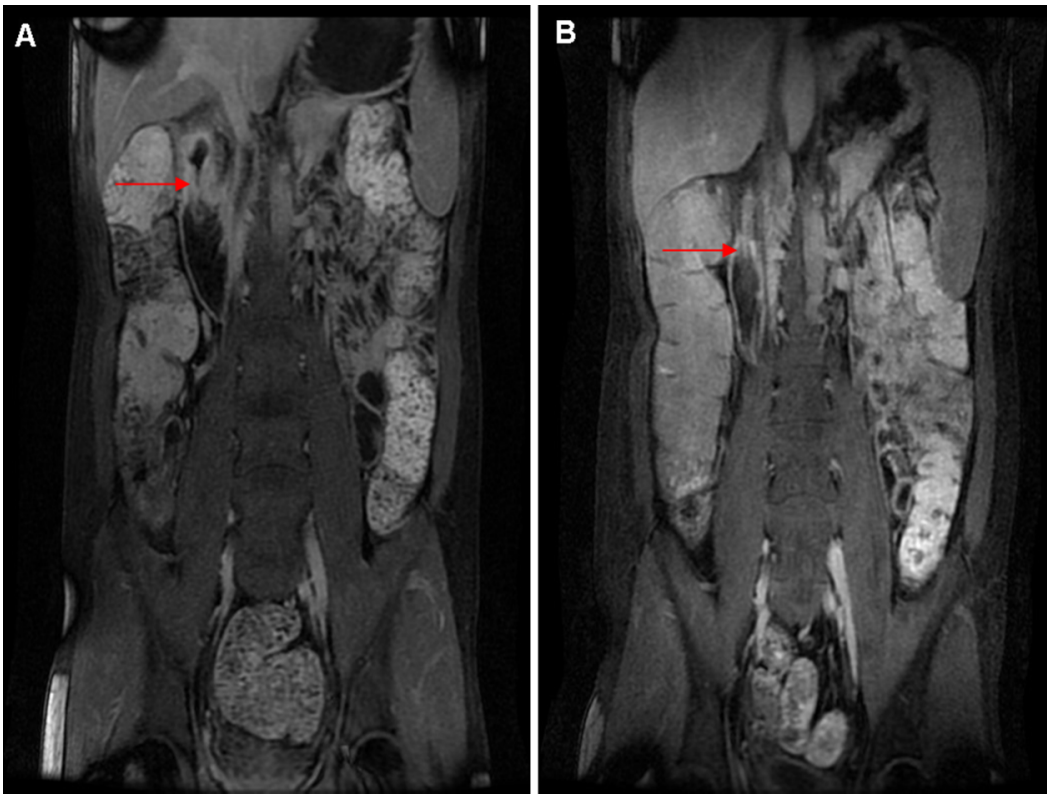

Figure 1 (A) MRI enterography showing irregular wall thickening and 4-5 cm constricting lesion at D1 and (B) showing complete improvement after 16 weeks.

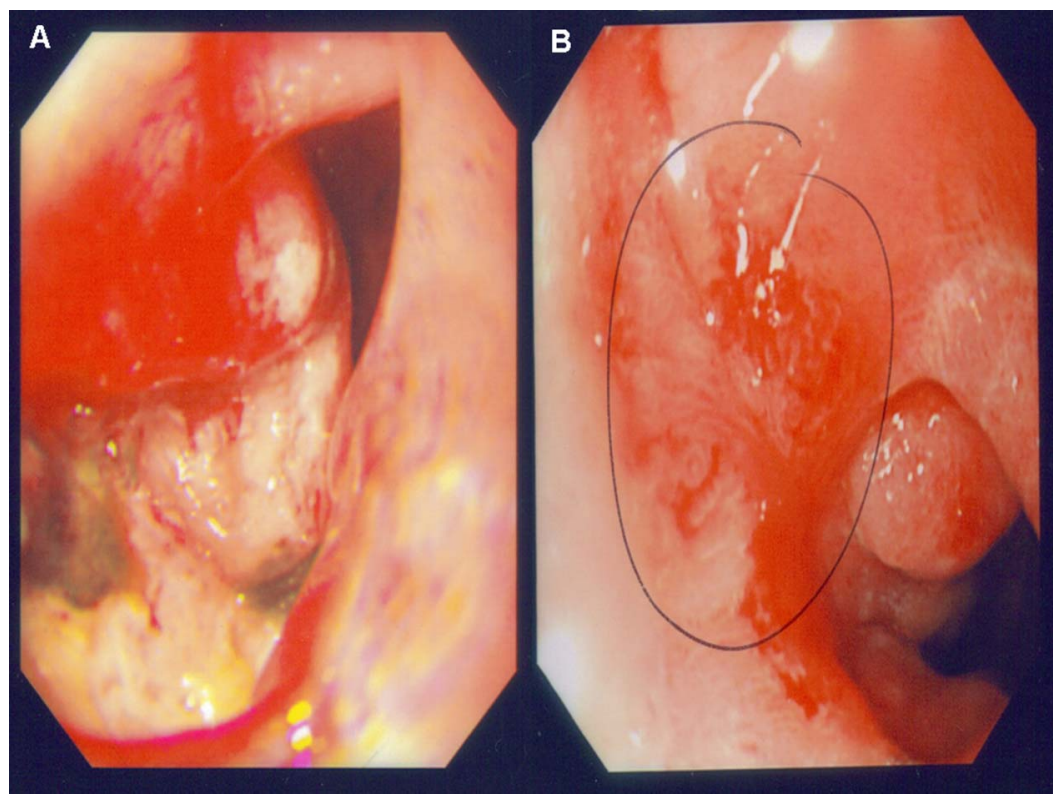

Figure 2 (A) Oesophagogastroduodenoscopy shows a large ulcerated mass at D1 and D2 junction and (B) showing healed ulcer with scarring after 10-week steroid treatment.
Haematological investigation revealed microcytic hypochromic anaemia with haemoglobin of $7.7 \mathrm{~g} / \mathrm{dl}$ and a mean corpuscular volume of $75 \mathrm{fl}$ while other values (including eosinophils) were within normal range. He received blood transfusion and
To cite: Selvam $\mathrm{K}$ Hassan A, Hossain F. BMJ Case Reports Published online: 2 January 2013 doi:10.1136/bcr-2012 007869 
underwent oesophagogastroduodenoscopy (OGD) and colonoscopy which were reported normal. However, routine biopsies taken during OGD showed a mixed inflammatory infiltrate with a high eosinophil count within the lamina propria with no evidence of malignancy.

Further investigation with an MRI enterography found evidence of irregular wall thickening and a $4-5 \mathrm{~cm}$ stricture with an enhancing irregular wall at D1/D2 with two slightly enlarged regional lymph nodes (figure $1 \mathrm{~A}$ ). To emphasise this, a repeat OGD showed the presence of a large ulcerated mass at the D1D2 junction (figure 2A). Biopsies taken were consistent with eosinophilic enteritis.

He was prescribed a 10 -week course of reducing regimen of steroids. Following this, he had an OGD which showed a healed ulcer with scarring (figure 2B). Two months later a repeat MRI enterography showed complete resolution in appearance of his D1 and D2 segments with residual small periduodenal lymph nodes (figure 1B).

\section{Learning points}

- MRI enterography is an imaging technique for small bowel disease that is increasingly more popular than $\mathrm{CT}$ or barium fluoroscopic examination because of the lack of ionising radiation exposure; improved contrast of the endoluminal, mural and extramural soft tissues. ${ }^{1}$

- MRI enterography can also be used to diagnose and monitor activity of inflammatory bowel diseases, identify neoplasms and structural abnormalities. ${ }^{2}$
Competing interests None.

Patient consent Obtained.

Provenance and peer review Not commissioned; externally peer reviewed.

\section{REFERENCES}

1 Masselli G, Gualdi G. CT and MR enterography in evaluating small bowel diseases: when to use which modality? Abdom Imaging. Published Online First: 26 September 2012. doi:10.1007/s00261-012-9961-8

2 Cronin CG, Lohan DG, DeLappe E, et al. Duodenal abnormalities at MR small-bowel follow-through. AJR Am J Roentgenol 2008;191:1082-92.

Copyright 2013 BMJ Publishing Group. All rights reserved. For permission to reuse any of this content visit http://group.bmj.com/group/rights-licensing/permissions.

BMJ Case Report Fellows may re-use this article for personal use and teaching without any further permission.

Become a Fellow of BMJ Case Reports today and you can:

- Submit as many cases as you like

- Enjoy fast sympathetic peer review and rapid publication of accepted articles

- Access all the published articles

- Re-use any of the published material for personal use and teaching without further permission

For information on Institutional Fellowships contact consortiasales@bmjgroup.com

Visit casereports.bmj.com for more articles like this and to become a Fellow 